\title{
Development of a new multiplex-PCR tool for the simultaneous detection of the fish pathogens Vibrio alginolyticus, Vibrio anguillarum, Vibrio harveyi and Edwardsiella tarda
}

\author{
Micaela Ferreira Pinto, Teresa Baptista and Clélia Correia Neves Afonso* \\ Instituto Politécnico de Leiria, Escola Superior de Turismo e Tecnologia do Mar, Peniche, Portugal
}

Received 14 October 2016 / Accepted 31 January 2017

\begin{abstract}
Disease assessment and management in cultured aquatic animals is a major concern in commercial aquaculture. Disease outbreaks have direct effects on fish production, causing serious economic losses in this industry. This can be overcome by early detection through molecular high sensitivity tools such as PCR (polymerase chain reaction). One of the most critical steps in the study of bacterial fish diseases is the precise identification of the infectious agent. Considering the damage that some bacteria can cause to fish and humans, the development of a rapid detection method for the four target species that demonstrates to be simple, accurate and low cost is an essential step for the prevention and early treatment of these diseases. Edwardsiella tarda (ACC 36.1), Vibrio harveyi (DSM 19023), Vibrio anguillarum (AQV 55.1) and Vibrio alginolyticus (CECT 521) were selected as targets of a multiplex PCR tool. The multiplex PCR reactions were performed in various reaction conditions, including different annealing temperatures (between $49^{\circ} \mathrm{C}$ and $55^{\circ} \mathrm{C}$ ) and changes in the $\mathrm{MgCl}_{2}$ concentration from $2 \mathrm{mM}$ to $8 \mathrm{mM}$. Best results were obtained at $51^{\circ} \mathrm{C}$ and $\mathrm{MgCl}_{2}$ concentration from $4 \mathrm{mM}$ to $6 \mathrm{mM}$. Primers were tested using purified DNA from the respective bacterial strains, yielding bands at expected sizes, which can be identified on agarose gels with clearness and without overlapping sizes. Results indicate that this multiplex PCR tool is suitable for the detection of target pathogens and may, in the future, have extended practical application in commercial aquaculture.
\end{abstract}

Keywords: Disease diagnostic / Multiplex-PCR / Vibrio alginolyticus / Vibrio anguillarum / Vibrio harveyi / Edwardsiella tarda

\section{Introduction}

Aquaculture is an emerging industrial sector which requires continued research with scientific and technical developments, and innovation. In nature, fish are continually bathed in an aqueous suspension of microorganisms and most of the members of the normal microflora of water are harmless, however some of these can reveal as bacterial fish pathogens (Chang et al., 2012). Although pathogenic species have been described in the majority of the existing taxonomic groups, only a relatively small number are responsible of important economic losses in cultured fish worldwide (Toranzo et al., 2005). The possibility of outbreaks is increased if fish are stressed, as what happens when the water temperature is inappropriate, or in conditions of low dissolved oxygen, high nitrite levels, or high culture densities (Perera et al., 1997; Shoemaker et al., 2000). Healthy looking fish without any clinical signs or lesions can carry pathogens and create a serious risk for spread of contagious diseases in fish

\footnotetext{
* Corresponding author: clelia@ipleiria.pt
}

populations (Onuk et al., 2010). Traditionally, disease diagnosis is obtained by culturing bacteria on agar plates followed by phenotypic and serological characterization of the pathogen, or by histological examination. Biochemical tests, DNA homology, and protease variability techniques have also been extensively used, but these techniques have major disadvantages, such as the need for initial isolation of the pathogen and insufficient sensitivity to detect low levels of pathogen. Molecular techniques have slowly established a place in the diagnosis of disease in aquaculture (Chatterjee and Haldar, 2012), by overcoming the problems related to the sensitivity and specificity of pathogen detection and identification (Altinok, 2011).

We have selected as development targets of a multiplex PCR tool the following pathogens: Vibrio alginolyticus, Vibrio anguillarum, Vibrio harveyi and Edwardsiella tarda. Vibrio species under optimum temperature and salinity conditions arise in high amounts in aquatic organisms (Espiñeira et al., 2010) and E. tarda has recently become an emerging bacterial pathogen in aquaculture (Castdermiro et al., 2014), affecting a wide range of cultivated species. It is associated with lifethreatening sepsis and infections in various animals, including 
humans (Castdermiro et al., 2014). Vibriosis is one of the most important and the oldest recognized fish disease in marine aquaculture worldwide (Gonzalez et al., 2003). The main feature of this bacterial group is their capability to cause serious alimentary intoxication associated with the consumption of raw or undercooked contaminated fish or shellfish, thus posing a considerable public health threat. Pathogenicity, frequency of relapses and their severity, determined the choice of these four species as targets. The development of this molecular tool is also important because it covers pathogens that affect a wide range of cultivated organisms such as bivalve mollusks, crustaceans and fish, decreasing costs for companies that already have different types of cultures and it may be a mean to encourage aquaculture companies to diversify their production.

In the past, individual PCR assays have been developed for detection and identification of these fish pathogens, resulting in a relatively costly and time-consuming process, consequently there has been much interest in the development of multiplex PCR (m-PCR) method, thus reducing cost, time and effort. Although simultaneous detection of several pathogens with a multiplex PCR (m-PCR) has been widely applied to the detection of multiple viruses and bacteria in clinical specimens, this approach has not been widely used in the detection of fish pathogens (Castdermiro et al., 2014), and reports of applications of these techniques on a routine basis in diagnostic laboratories are few (Chatterjee and Haldar, 2012). Several attempts to develop methods for the rapid and accurate diagnosis of edwardsiellosis have been made, including PCRbased methods (Castdermiro et al., 2014). Of these, a PCR protocol employing the gene etfD (which encodes the upstream region of the fimbrial gene) reported by Sakai et al. (2007) was shown to be the most rapid and sensitive method for the accurate detection of E. tarda in infected fish (Castdermiro et al., 2014). In 2006, Fukui and Sawabe (2007) modified the method developed by Bramha Chari and Dubey (2006) and developed a one-step colony PCR targeting the 16S rRNA gene to identify pathogenic $V$. harveyi from aquaculture settings (Fukui and Sawabe, 2007; Chatterjee and Haldar, 2012). Similarly, Conejero and Hedreyda in 2003 targeted the toxR gene for identification of $V$. harveyi from aquaculture systems (Conejero and Hedreyda, 2003; Chatterjee and Haldar, 2012). However, the most precise method to identify $V$. harveyi along with $V$. campbellii and V. parahaemolyticus was developed by Haldar et al. (2010), using a multiplex PCR tool. The main drawback of molecular methodology is that it does not discriminate between DNA from alive and dead microorganisms (Espiñeira et al., 2010). Success of this method depends on the selection of target genes, which should be species-specific, widely distributed and also stable in the genome (Chatterjee and Haldar, 2012). Considering the damages that some bacteria can cause to humans and fish, it is necessary to have a fast, simple, simultaneous (detection of different pathogens in one single reaction at the same time) and low cost detection method, being the primary objective of this study.

\section{Materials and methods}

\subsection{Bacterial strains and culture conditions}

Four bacterial pathogen species were used in this study: Edwardsiella tarda (ACC 36.1), Vibrio harveyi (DSM
19023), Vibrio anguillarum (AQV 55.1) and Vibrio alginolyticus (CECT 521). The strains Edwardsiella tarda (ACC 36.1) and Vibrio anguillarum (AQV 55.1) used in the present study, virulent for teleost fishes from aquaculture, were kindly provided by Professor Alicia E. Toranzo (Departamento de Microbiología y Parasitología, Facultad de Biología, University of Santiago de Compostela, Spain). Bacteria were cultured on Tryptone Soya Broth (TSB; Himedia), supplemented with $1.5 \%$ of sodium chloride ( $\mathrm{NaCl}$; Panreac), except for $E$. tarda that was cultured with $1 \%$ sodium chloride.

\subsection{DNA extraction and PCR conditions}

Bacterial DNA extraction was made with the NZY Tissue gDNA isolation kit (Nzytech, genes \& enzymes) as indicated in the kit instructions. Bacterial DNA was quantified with a Nanodrop 2000 Spectrophotometer (Thermo scientific) in $n g \mathrm{l}^{-1}$. Individual PCR reactions were performed with the NZYTaq $2 \times$ Colourless Master Mix, with $2.5 \mathrm{mM} \mathrm{MgCl}_{2}$, $0.125 \mu \mathrm{M}$ of each primer and template DNA $\left(64.6 \mathrm{ng}_{\mu l^{-1}}\right.$

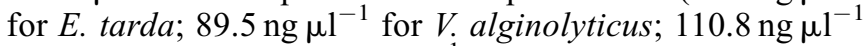
for $V$. anguillarum; $24 \mathrm{ng}_{\mu l^{-1}}$ for $V$. harveyi). The PCR reaction was initiated with a denaturation of $5 \mathrm{~min}$ at $95^{\circ} \mathrm{C}$, followed by 45 cycles of denaturation for $30 \mathrm{~s}$ at $95^{\circ} \mathrm{C}$, annealing $30 \mathrm{~s}$ at $51{ }^{\circ} \mathrm{C}$ and extension for $1 \mathrm{~min}$ at $72^{\circ} \mathrm{C}$. The final extension step consisted of $10 \mathrm{~min}$ at $72^{\circ} \mathrm{C}$. Amplified products were separated on agarose gel at $1.5 \%(\mathrm{w} / \mathrm{v})$ with $1 \times$ TAE buffer and visualized in UV transilluminator. The horizontal electrophoresis ran for $60 \mathrm{~min}$ at a voltage of $70 \mathrm{~V}$. Primers used in this study are listed in Table 1 with respective target bacteria, name, forward and reverse sequences, melting temperatures $\left({ }^{\circ} \mathrm{C}\right)$ and expected size band (bp). EtdF primer was design with the help tool PrimerBlast from NCBI (http://www.ncbi.nlm.nih.gov/tools/prim er-blast/) (Ye et al., 2012).

\section{3 m-PCR analysis}

Multiplex-PCR reactions were tested using the NZYTaq $2 \times$ Colourless Master Mix, separate $\mathrm{MgCl}_{2}$ (MB04902), with variable annealing temperatures $\left(49^{\circ} \mathrm{C}, 51^{\circ} \mathrm{C}, 53^{\circ} \mathrm{C}\right.$ and $55^{\circ} \mathrm{C}$ ) and $0.125 \mu \mathrm{M}$ of each primer. The $\mathrm{PCR}$ reactions were initiated with a denaturation of $5 \mathrm{~min}$ at $95^{\circ} \mathrm{C}$, followed by 45 cycles of denaturation for $30 \mathrm{~s}$ at $95^{\circ} \mathrm{C}$, annealing $30 \mathrm{~s}$ at the indicated temperature and extension for $1 \mathrm{~min}$ at $72^{\circ} \mathrm{C}$. The final extension step consisted of $10 \mathrm{~min}$ at $72^{\circ} \mathrm{C}$. m-PCR reactions were also made with variable concentrations of $\mathrm{MgCl}_{2}$ (2, 4, 6 and $\left.8 \mathrm{mM}\right)$, maintaining annealing temperatures and conditions mentioned above. All reaction products were analyzed by electrophoresis in agarose gel (1.5\%), using a $250 \mathrm{bp}$ ladder (Alfa Aesar) as a molecular weight marker, and visualized in UV transilluminator. Sensitivity was tested with eight successive dilutions of a mixture of the four bacterial pathogens purified DNA from a known concentration of $64.6 \mu \mathrm{g} \mathrm{ul}^{-1}$ for E. tarda; $89.5 \mu \mathrm{g} \mu \mathrm{l}^{-1}$ for V. alginolyticus; $110.8 \mu \mathrm{g} \mathrm{Ml}^{-1}$ for $V$. anguillarum and $24 \mu \mathrm{g} \mu \mathrm{l}^{-1}$ for $V$. harveyi. Amplifications conditions were the same used for specificity testing. 
Table 1. Characteristics of the primers used in this study and their references.

\begin{tabular}{|c|c|c|c|c|c|}
\hline Target bacteria & $\begin{array}{l}\text { Primer } \\
\text { name }\end{array}$ & Sequences $\left(5^{\prime}-3^{\prime}\right)$ & $\begin{array}{l}\text { Melting } \\
\text { temperature }\left({ }^{\circ} \mathrm{C}\right)\end{array}$ & $\begin{array}{l}\text { Expected } \\
\text { size }(b p)\end{array}$ & References \\
\hline E. $\operatorname{tarda}$ & EtdF & AGCGCAGCTAACGGTAAAGT & 57 & 426 & This study \\
\hline \multirow{2}{*}{ V. alginolyticus } & ValF & СТСТСССАATTCAGCССТСТА & 56 & \multirow{2}{*}{773} & Ransangan and Lal (2013) \\
\hline & ValR & GACTCTTCACAACAGAACTC & 51 & & Ransangan and Lal (2013) \\
\hline V. anguillarum & rpoN-ang5 & GTTCATAGCATCAATGAGGAG & 51 & 519 & Demircan and Candan (2006) \\
\hline V. harveyi & VhR & CTTCGCACCTGCATCGG & 57 & 606 & Ransangan and Lal (2013) \\
\hline
\end{tabular}

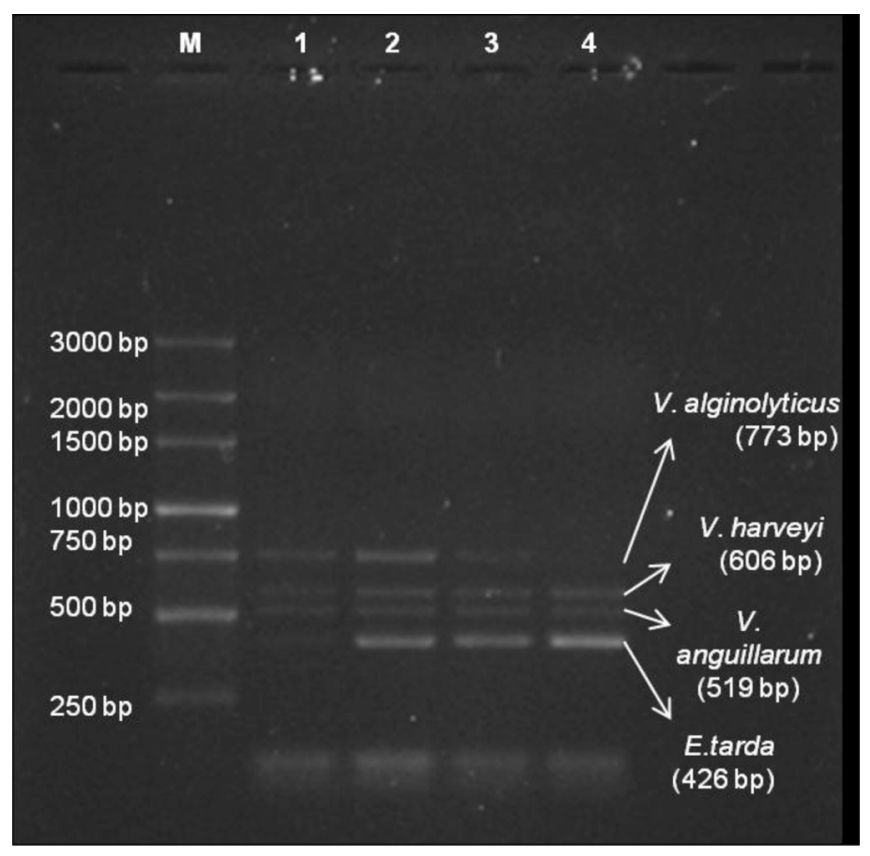

Fig. 1. Multiplex PCR at different annealing temperatures. M: $250 \mathrm{bp}$ ladder; lane $1: 49^{\circ} \mathrm{C}$; lane 2: $51^{\circ} \mathrm{C}$; lane $3: 53^{\circ} \mathrm{C}$; lane $4: 55^{\circ} \mathrm{C}$.

\section{Results}

\section{1 m-PCR analysis}

Four different annealing temperatures $\left(49^{\circ} \mathrm{C}, 51^{\circ} \mathrm{C}, 53^{\circ} \mathrm{C}\right.$ and $55^{\circ} \mathrm{C}$ ) were tested and we obtained four bands with the expected size (E. tarda $-426 \mathrm{bp}$; V. anguillarum $-519 \mathrm{bp}$; V. harveyi $-606 \mathrm{bp} ;$ V. alginolyticus $-773 \mathrm{bp})$ at $49{ }^{\circ} \mathrm{C}, 51^{\circ} \mathrm{C}$ and $53{ }^{\circ} \mathrm{C}$ and only three bands at $55^{\circ} \mathrm{C}($ E. tarda $-426 \mathrm{bp}$; $V$. anguillarum $-519 \mathrm{bp} ; V$. harveyi $-606 \mathrm{bp}$ ). We concluded that the temperature of $51{ }^{\circ} \mathrm{C}$ is better to distinguish the bands of four different pathogens: E. tarda, $V$. anguillarum, $V$. harveyi and $V$. alginolyticus (Fig. 1).

Different concentrations of $\mathrm{MgCl}_{2}(2 \mathrm{mM}, 4 \mathrm{mM}, 6 \mathrm{mM}$ and $8 \mathrm{mM}$ ) were also tested along the different annealing temperatures mentioned above and the results obtained were the four expected size bands (E. tarda - 426bp; $V$. anguillarum $-519 \mathrm{bp} ; V$. harveyi $-606 \mathrm{bp} ;$ V. alginolyticus $-773 \mathrm{bp}$ ). It follows that the temperature of $51^{\circ} \mathrm{C}$ along with
4-6 $\mathrm{mM}$ of $\mathrm{MgCl}_{2}$ is better to distinguish the bands of the four different pathogens: E. tarda, V. anguillarum, $V$. harveyi and $V$. alginolyticus (Fig. 2).

\subsection{Sensitivity of m-PCR assay}

Primers were tested using purified bacterial DNA of the respective strains, yielding bands at expected sizes (E. tarda$426 \mathrm{bp} ;$ V. anguillarum - $519 \mathrm{bp} ;$ V. harveyi - $606 \mathrm{bp}$; $V$. alginolyticus - $773 \mathrm{bp}$ ), which could be identified on agarose gels with clearness and without overlapping sizes (Fig. 3). The detection limit of the multiplex PCR amplification

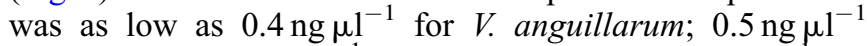

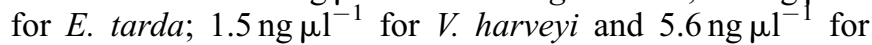
V. alginolyticus (Fig. 4).

\section{Discussion}

Currently, aquaculture is one of the fastest growing food production systems in the world (Castdermiro et al., 2014). Disease management and assessment of cultured aquatic animals is a major concern in commercial aquaculture (Shi et al., 2012) and the molecular methods like PCR and multiplex-PCR are always more reliable to overcome pathology problems, being the last one more efficient due to multiple detection of pathogens in an only reaction. Multiplex-PCR is generally thought to be less sensitive than single PCR because of competition for reaction reagents, especially if the assays differ in their amplification efficiencies or one or more of the target organisms is present in high numbers (Tapia-Cammas et al., 2011; Castdermiro et al., 2014). Products of various lengths present a challenge for developing optimal PCR conditions (primer annealing temperatures and similar $\mathrm{MgCl}_{2}$ concentrations) (Gonzalez et al., 2004) and in the present work, several reaction conditions were tested for the development of this tool, including varying annealing temperatures (between $49^{\circ} \mathrm{C}$ and $55^{\circ} \mathrm{C}$ ) and the variation in the $\mathrm{MgCl}_{2}$ concentration (from $2 \mathrm{mM}$ to $8 \mathrm{mM}$ ). Best results were obtained at $51{ }^{\circ} \mathrm{C}$ with an $\mathrm{MgCl}_{2}$ concentration between $4 \mathrm{mM}$ and $6 \mathrm{mM}$ where it appears the bands of the four pathogens tested (E. tarda, V. alginolyticus, $V$. anguillarum and $V$. harveyi) (Fig. 2). One of the most critical steps in the study of bacterial fish diseases is the correct identification of the infectious agent (AvendañoHerrera et al., 2004). The primers described here proved to be 


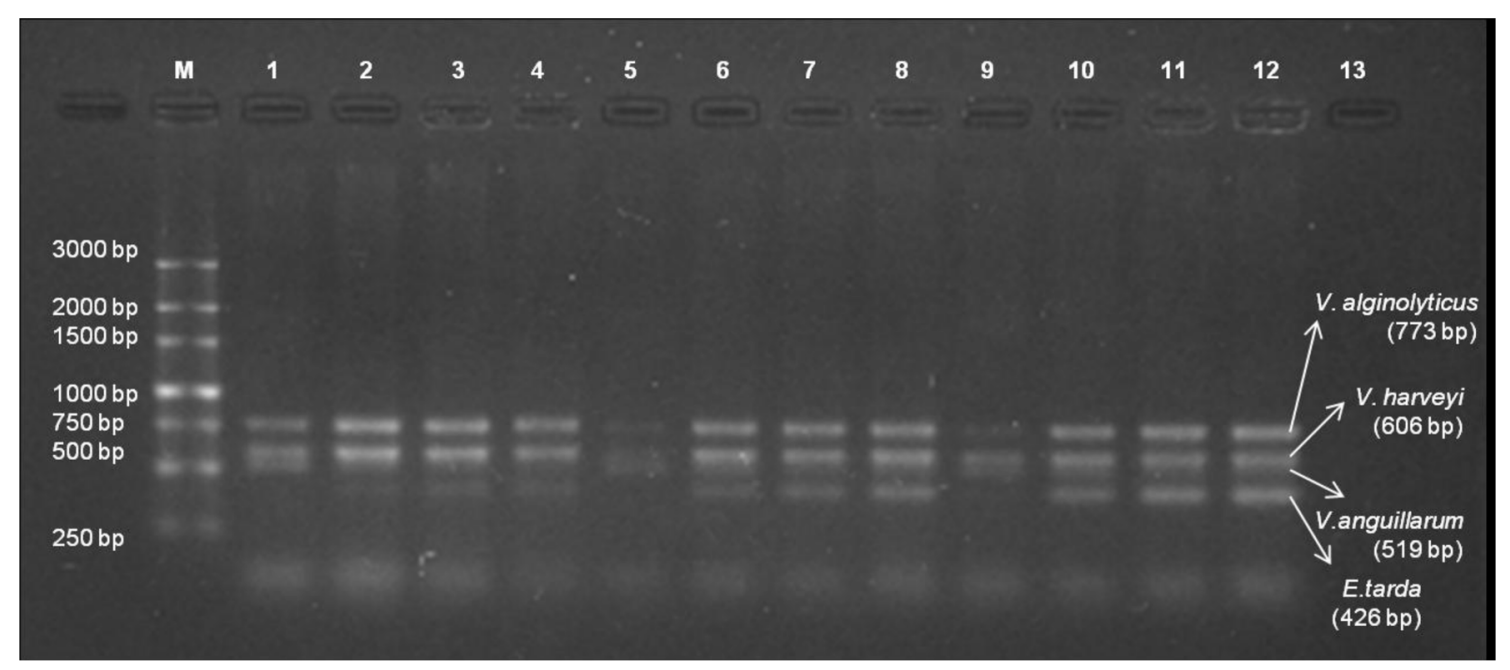

Fig. 2. Multiplex-PCR at different annealing temperatures and different concentrations of $\mathrm{MgCl}_{2}$. Lane $1-250$ bp ladder; lanes $2-5: 49{ }^{\circ} \mathrm{C}$; lanes 6-9: $51^{\circ} \mathrm{C}$; lanes 10-13: $53{ }^{\circ} \mathrm{C}$; lanes 2, 6, 10: $2 \mathrm{mM} \mathrm{MgCl}_{2}$; lanes 3, 7, 11: $4 \mathrm{mM} \mathrm{MgCl}_{2}$; lanes 4, 8, 12: $6 \mathrm{mM} \mathrm{MgCl}_{2} ;$ lanes 5, 9, 13: $8 \mathrm{mM}$ $\mathrm{MgCl}_{2}$.

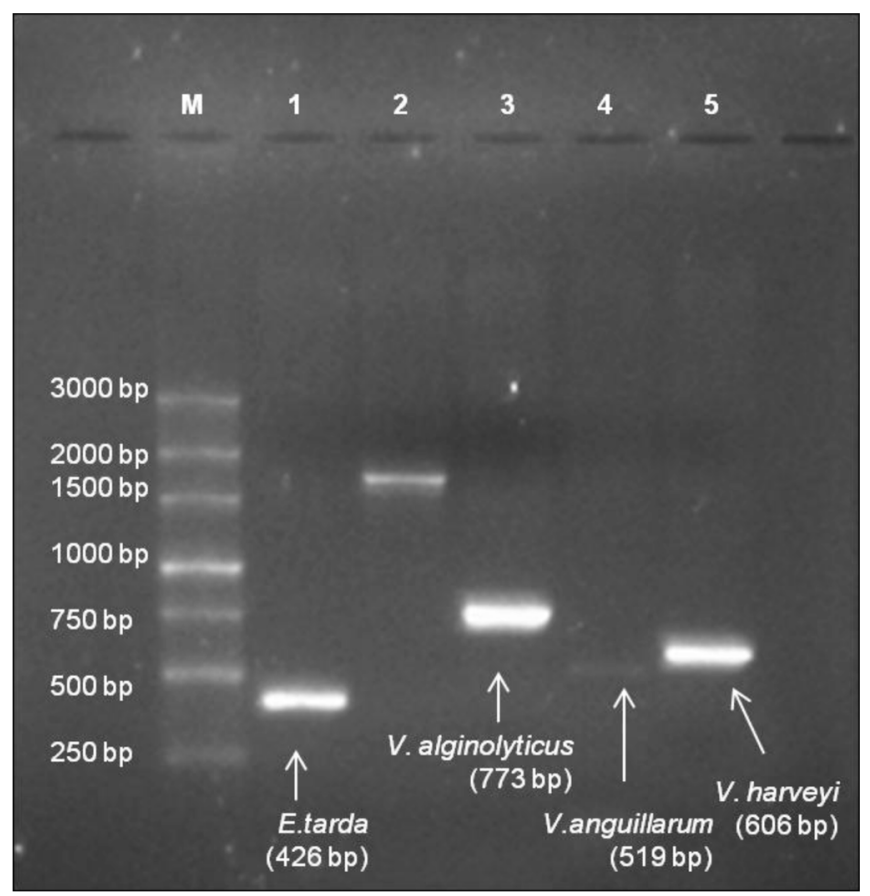

Fig. 3. Amplification of assay primers in monoplex reaction. $\mathrm{M}-$ $250 \mathrm{bp}$ ladder; lane $1-E$. tarda (369 bp); lane $3-V$. alginolyticus (773 bp); lane $4-V$. anguillarum $(519 \mathrm{bp})$; lane $5-V$. harveyi (606 bp).

specific under the conditions assayed, with only the specific target species showing amplification in the multiplex reaction (Fig. 3) and presented a satisfactory detection limit (Fig. 4). Under intensive aquaculture conditions, healthy-looking fish without clinical signs may carry pathogens, posing a serious risk for the spread of diseases among fish populations (Castdermiro et al., 2014). Therefore, precise and early detection of pathogens in fish is essential for effective disease control (Altinok, 2011). Even though, and according to
Lievens et al. (2011), until 2011, it has not been reported the utility of the system for sensitive detection from complex samples, such as infected tissue. The results indicate that the multiplex PCR tool is suitable for detection of the four major pathogens tested (E. tarda, V. harveyi, $V$. anguillarum and $V$. alginolyticus). This method allows a diagnosis of edwardsiellosis and vibriosis in one working day; thus, it appears more convenient than the classical culture based methods, which are time consuming and not always certain because of variability in phenotypic characters depending on growth conditions. In summary, the optimum m-PCR protocol for the detection of E. tarda, $V$. alginolyticus, $V$. anguillarum and $V$. harveyi in fish consists of an annealing temperature of $51{ }^{\circ} \mathrm{C}$ and amplification for 45 cycles using the primers mentioned in Table 1. The PCR protocol described here has practical application for the rapid and early diagnosis of edwardsiellosis and different types of vibriosis. This PCR protocol could potentially be used to monitor these diseases in species of fish form aquaculture.

\section{Conclusion}

Although the molecular methods such as PCR and multiplex-PCR can bring multiple advantages, they may vary in amplification efficiency. In a multiplex PCR assay, and due to differences in primer length, nucleotide content and secondary structure, a target in high concentration might outcompete one or more of the other primers. Consequently, the detection limits for the targets at lower concentrations might become affected (Altinok, 2011). In general, it is not easy to incorporate more than six primer sets because of the cross-reaction in $\mathrm{m}-\mathrm{PCR}$, and the challenges inherent in size discrimination among PCR products by conventional electrophoresis (Warsen et al., 2004). The work carried out allowed us to establish the primer sequences and PCR multiplexing conditions, targeting 4 bacterial pathogens, which are currently the subject of strong concerns in the commercial aquaculture 


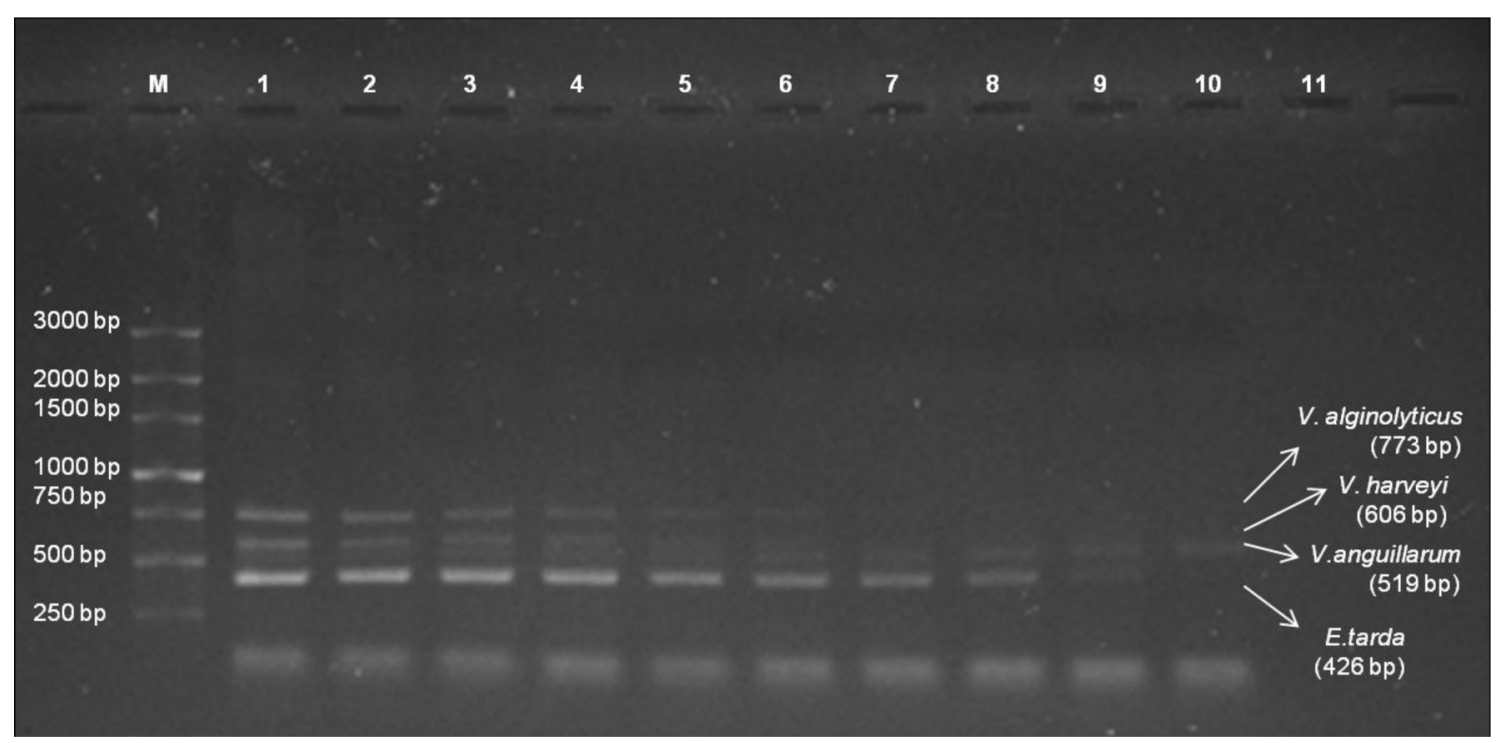

Fig. 4. Multiplex-PCR sensitivity test. Lane $1-250$ bp ladder; lane 2 - mixture of different DNA (64.6 ng $\mu l^{-1}$ for $E$. tarda; $89.5 \mathrm{ng} \mu \mathrm{l}^{-1}$ for

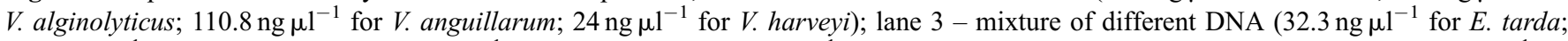

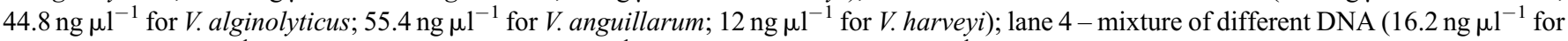

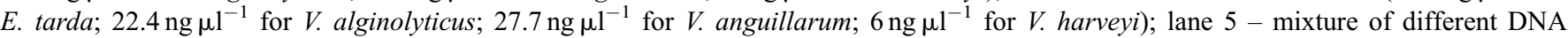

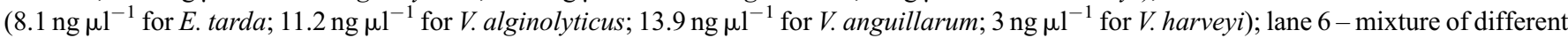

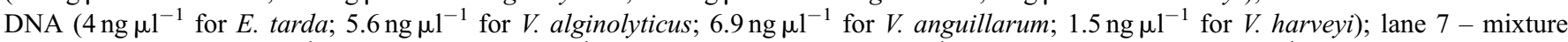

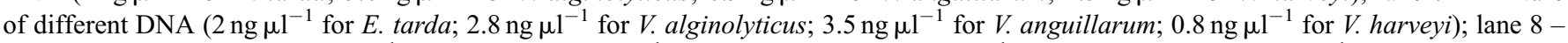

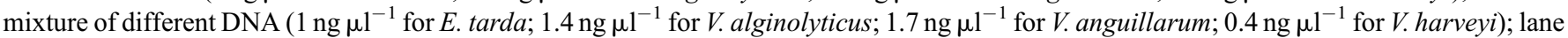

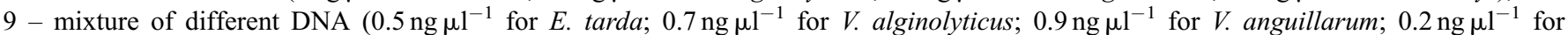
V. harveyi); lane 10 - mixture of different DNA $\left(0.3 \mathrm{ng} \mu \mathrm{l}^{-1}\right.$ for E. tarda; $0.3 \mathrm{ng} \mu \mathrm{l}^{-1}$ for V. alginolyticus; $0.4 \mathrm{ng} \mu \mathrm{l}^{-1}$ for $V$. anguillarum; $0.1 \mathrm{ng} \mu \mathrm{l}^{-1}$ for $V$. harveyi); lane 11 - control of the reaction, without DNA.

sector. These species can cause extensive damage and high losses and their early and rigorous detection is of fundamental importance. In future studies this tool must be improved through quantification of the sensitivity of the tool for blood samples and by testing it in a set of samples from farmed fish species.

Acknowledgements. This study had the support of Fundação para a Ciência e Tecnologia (FCT), through the strategic project UID/MAR/04292/2013 granted to MARE.

\section{References}

Altinok I. 2011. Multiplex PCR assay for detection of four major bacterial pathogens causing rainbow trout disease. Dis Aquat Org 93: 199-206.

Avendaño-Herrera R, Magariños B, Toranzo AE, Beaz R, Romalde JL. 2004. Species-specific polymerase chain reaction primers sets for the diagnosis of Tenacibaculum maritimum infection. Dis Aquat Org 62: 75-83.

Bramha Chari PV, Dubey SK. 2006. Rapid and specific detection of luminous and non-luminous Vibrio harveyi isolates by PCR amplification. Curr Sci 90 (8): 1105-1108.

Castdermiro N, Toranzo AE, Magariños B. 2014. A multiplex PCR for the simultaneous detection of Tenacibaculum maritimum and Edwardsiella tarda in aquaculture. Int Microbiol 17: 111-117.
Chang C-I, Hung P-H, Wu C-C, et al. 2012. Simultaneous detection of multiple fish pathogens using a naked-eye readable DNA microarray. Sensors 12: 2710-2728.

Chatterjee S, Haldar S. 2012. Vibrio related diseases in aquaculture and development of rapid and accurate identification methods. J Mar Sci Res Dev S1: 002.

Conejero MJU, Hedreyda CT. 2003. Isolation of partial toxR gene of Vibrio harveyi and design of toxR-targeted PCR primers for species detection. J Appl Microbiol 95: 602-611.

Demircan D, Candan A. 2006. Identification of Vibrio anguillarum by PCR (rpoN Gene) associated with vibriosis in marine fish in Turkey. Turk J Vet Anim Sci 30: 305-310.

Espiñeira M, Atanassova M, Vieites JM, Santaclara FJ. 2010. Validation of a method for the detection of five species, serogroups, biotypes and virulence factors of Vibrio by multiplex PCR in fish and seafood. Food Microbiol 27: 122-131.

Fukui Y, Sawabe T. 2007. Improved one-step colony PCR detection of Vibrio harveyi. Microbes Environ 22 (1): 1-10.

Gonzalez SF, Osorio CR, Santos Y. 2003. Development of a PCR-based method for the detection of Listonella anguillarum in fish tissues and blood samples. Dis Aquat Org 55: 109-115.

Gonzalez SF, Krug MJ, Nielsen ME, Santos Y, Call DR. 2004. Simultaneous detection of marine fish pathogens by using multiplex PCR and a DNA microarray. J Clin Microbiol 42 (4): 1414.

Haldar S, Neogi SB, Kogure K, et al. 2010. Development of a haemolysin gene-based multiplex PCR for simultaneous detection of Vibrio campbellii, Vibrio harveyi and Vibrio parahaemolyticus. Lett Appl Microbiol 50: 146-152. 
Lievens B, Frans I, Heusdens C, et al. 2011. Rapid detection and identification of viral and bacterial fish pathogens using a DNA array-based multiplex assay. J Fish Dis 34: 861-875

Onuk EE, Ciftci A, Findik A, Durmaz Y. 2010. Development and evaluation of a multiplex PCR assay for simultaneous detection of Flavobacterium psycrophilum, Yersinia ruckeri and Aeromonas salmonicida subsp. salmonicida in culture fisheries. J Vet Sci 11 (3): 235-241.

Perera RP, Johnson SK, Lewis DH. 1997. Epizootiological aspects of Streptococcus iniae affecting tilapia in Texas. Aquaculture 152: 25-33.

Ransangan J, Lal MMT. 2013. Simultaneous detection of Photobacterium damselae, Vibrio alginolyticus, Vibrio harveyi and Vibrio parahaemolyticus using multiplexPCR amplification method. Int Res J Biol Sci 2 (12): 79-84.

Sakai T, Iida T, Osatomi K, Kanai K. 2007. Detection of type 1 fimbrial genes in fish pathogenic and non-pathogenic Edwardsiella tarda strains by PCR. Fish Pathol 42 (2): 115-117.
Shi Y-H, Chen J, Li CH, et al. 2012. Detection of bacterial pathogens in aquaculture samples by DNA microarray analysis. Aquaculture 338-341: 29-35.

Shoemaker CA, Evans JJ, Klesius PH. 2000. Density and dose: factors affecting mortality of Streptococcus iniae infected tilapia (Oreochromis niloticus). Aquaculture 188: 229-235.

Tapia-Cammas D, Yañez A, Arancibia G, Toranzo AE, AvendañoHerrera R. 2011. Multiplex PCR for the detection of Piscirickettsia salmonis, Vibrio anguillarum, Aeromonas salmonicida and Streptococcus phocae in Chilean marine farms. Dis Aquat Org 97: 135-142.

Toranzo AE, Magariños B, Romalde JL. 2005. A review of the main bacterial fish diseases in mariculture systems. Aquaculture 246: 37-61.

Warsen AE, Krug MJ, LaFrentz S, Stanek DR, Loge FJ, Call DR. 2004. Simultaneous discrimination between 15 fish pathogens by using $16 \mathrm{~S}$ ribossomal DNA PCR and DNA microarrays. Appl Environ Microbiol 70 (7): 4216-4221.

Ye J, Coulouris G, Zaretskaya I, Cutcutache I, Rozen S, Madden T. 2012. Primer-BLAST: a tool to design target-specific primers for polymerase chain reaction. BMC Bioinformatics 13: 134.

Cite this article as: Pinto MF, Baptista T, Neves Afonso CC. 2017. Development of a new multiplex-PCR tool for the simultaneous detection of the fish pathogens Vibrio alginolyticus, Vibrio anguillarum, Vibrio harveyi and Edwardsiella tarda. Aquat. Living Resour. $30: 4$ 